\title{
OS REFLEXOS NO CONCEITO CONTEMPORÂNEO DA DECISÃO DE MÉRITO NA AÇÃO RESCISÓRIA
}

\section{REFLECTIONS ON THE CONTEMPORARY CONCEPT OF MERITS IN THE TERMINATION ACTION}

Márcia Regina Lobato ${ }^{1}$

\section{RESUMO}

A ação rescisória tinha como ponto de partida a sentença de mérito. $O$ conceito de sentença se altera no Código de Processo Civil de 2015, e ainda o mérito pode ser conhecido fora da peça processual que põe termo ao processo. Tais alterações ganham status de verdadeira revolução dentro da ciência processual, razão pela qual a atualização do instituto se impõe. Considerando-se ainda que o padrão normativo oferecido para o desenvolvimento da ação rescisória na Justiça do Trabalho é o mesmo do processo civil, e que a procedimentalidade contempla situações distintas de aplicabilidade, o reexame da matéria concita a formação de nova doutrina.

Palavras-chave: Mérito; Ação Trabalhista; Rescisória.

\begin{abstract}
The termination action had as its starting point the sentence of merit. The concept of sentence changed in the Civil Code of 2015, and now merit can be analyzed outside the procedural piece that ends the process. Such changes present status of true revolution within the procedural science, reason that justifies the update of the institute. Considering also that the normative standard offered for the development of the Termination Action in the Labor Court is the same of the civil process, and that the procedimentality contemplates different situations of applicability, the reexamination of the matter calls for the formation of a new doctrine.
\end{abstract}

Keywords: Merit; Labor action; Termination.

\footnotetext{
${ }^{1}$ Doutoranda e Mestre em Direito pela Pontifícia Universidade Católica de Minas Gerais. Especialista em Direito do Trabalho, Graduada em Direito pela Faculdade Milton Campos e Administração de Empresas. Professora de Direito Processual do Trabalho e Direito do Trabalho. Diretora de Secretaria de Seções Especializadas no Tribunal Regional do Trabalho - 3a Região (MG). E-mail: lobatomarciarc@gmail.com
} 


\section{INTRODUÇÃO}

O instituto da ação rescisória ostenta a natureza de ação autônoma e impugnativa que, consoante à orientação traçada pelo Código de Processo Civil de 1973, tem por objetivo se insurgir contra "sentença de mérito", transitada em julgado, supostamente eivada de vícios de ilegalidade decorrentes de error in procedendo ou de error in judicando. O atual Diploma concebeu, no entanto, inovações e alterações no sistema jurídico processual, com reflexos também no Processo do Trabalho. Essas modificações não foram apenas pontuais, todavia, no presente ensaio pretende-se colocar em evidência o alcance da expressão "decisão judicial" inserida no caput do art. 966 do CPC de 2015, em substituição à "sentença de mérito" constante do preceito da codificação antecedente.

Nesse contexto, torna-se imperioso um exame sobre a atual concepção doutrinária relacionada às modalidades de decisão meritória passíveis de rescindibilidade, assim como sobre os reflexos jurídicos daí decorrentes. Aliada a essa pretensão, é fundamental decifrá-las sob a ótica contemporânea, enquadrandoas na atual realidade processual no âmbito da Justiça do Trabalho.

A despeito de a coisa julgada ter assento constitucional como direito fundamental indispensável ao Estado Democrático, coibindo ao Poder Judiciário de decidir novamente questões já apreciadas, há pronunciamentos judiciais meritórios, cujo trânsito em julgado já se consumou, mas que, por contrariarem cabalmente a lógica, não devem e não podem subsistir no cenário jurídico.

Com base nessa premissa, citar-se-ão as hipóteses, numerus clausus, enumeradas pelo já citado art. 966 as quais, excepcionalmente, autorizam o rompimento da res judicata, realçando, porém, que o exame do rol dos preceitos que compõem o nominado artigo limitar-se-ão, unicamente, às inovações e alterações contempladas pelo CPC de 2015, consideradas relevantes.

A existência de lacunas para disciplinar o instituto da ação rescisória no âmbito da Justiça do Trabalho provoca indagações. Exsurge daí a indispensável reflexão e o debate jurídico sobre a real necessidade da aplicação das regras 
processuais civilistas, subsidiária e supletivamente, considerando que a autonomia e os princípios que regem a ciência jurídica processual trabalhista por si só já atraem a indiscutível imposição de se criarem procedimentos específicos voltados exclusivamente a reger o instituto rescisório também nesta seara, de maneira que possa corroborar com a celeridade que se busca consagrar nesse ramo processual.

\section{NOVO CONCEITO SENTENÇA DE MÉRITO E OS SEUS EFEITOS FRENTE À AÇÃO RESCISÓRIA}

A ação rescisória como modalidade de ação autônoma e impugnativa tem por finalidade rescindir a coisa julgada material, consumada em face de uma decisão meritória proferida em processo antecedente. Desse modo, excepcionalmente, pela via desse mecanismo torna-se possível o reexame de matéria já apreciada em processo originário.

Do ponto de vista processual contemporâneo, é imperiosa uma releitura acerca da sentença meritória judicial, cuja rescindibilidade pode vir a se buscar. Com a evolução da ciência jurídica processual conferiu-se uma interpretação mais ampliativa à expressão "sentença de mérito" de maneira que esta deverá ser compreendida como uma das espécies do gênero decisão judicial, ato complexo e multifacetário, por meio do qual o juiz, após uma apuração exauriente, buscando aplicar, com maestria jurídica, inerente à aptidão judicante, o comando abstrato da lei ao caso concreto.

Partindo dessa premissa, considera-se inexorável uma investigação sobre a sentença judicial no atual cenário processual, mostrando-se relevante o cotejo entre a codificação processual civil pretérita e o texto da norma correlata contemplada pelo atual Diploma Processual.

Analisando a redação do caput do art. 966 do Código de Processo Civil de 2015 antevê-se a viabilidade de se rescindir, por meio da ação rescisória, após consumado o trânsito em julgado, a "decisão de mérito", o que a codificação processual de 1973, no caput do art. 485, de outra maneira previa a igual 
possibilidade, todavia em desfavor da "sentença de mérito" (BRASIL, 2015, grifos nossos).

Uma leitura dinâmica, a priori, poderia conduzir o intérprete a concluir que a alteração do vocábulo seria irrelevante, porquanto sentença de mérito abarcaria todas as decisões que se relacionassem ao pedido principal ou à matéria de fundo objeto da demanda. Em verdade, contudo, não é bem assim. A partir de uma reflexão sobre essa questão, percebe-se a mutabilidade das relações interpessoais, assim como das jurídicas e das sociais. Assim, a ciência jurídica também não é como não deve ser estática, o que exige do operador do direito que acompanhe as incessantes e naturais metamorfoses presentes no cotidiano jurídico.

Em vista disso, passa-se à análise do texto processual a que se refere 0 caput do art. 966 do CPC de 2015, segundo o qual autoriza-se a rescindibilidade da "decisão de mérito", transitada em julgado nas hipóteses elencadas no rol do artigo em questão.

Para Fredie Didier Jr. e Leonardo Carneiro Cunha (2016, p. 423) essa mudança não foi imprevisível, já que a intenção do legislador revela-se bastante clara com intuito de se "permitir o ajuizamento da ação rescisória contra qualquer tipo de decisão de mérito: decisão interlocutória, sentença, decisão de relator ou acórdão". Isso alarga o campo de aplicação para o fim de desconstituição de tais decisões. É preciso, alertar, porém, para o fato de esse alcance diz respeito ao rol das causas que autorizam a rescisão do julgado.

Transplantando essas considerações para o plano do Processo do Trabalho, tem-se que seriam rescindíveis, em $1^{\circ}$ grau de jurisdição, as decisões de conteúdo decisório proferidas pelo juízo, incluindo-se, aí, a interlocutória e a sentença prolatada ao final da reclamação trabalhista.

Nas lições clássicas de Cândido Rangel Dinamarco (2001, p. 30), "o demandar-contestar-conhecer-julgar" são elementos típicos que compõem o caminho a ser perseguido para se obter a tutela jurisdicional. Instalado o devido processo legal, oportuniza-se ao reclamado opor-se à demanda apresentada já que 
ao reclamante viabilizou-se a possibilidade de requerer em juízo eventual direito propiciando-lhe externar as suas razões, de fato e de direito.

Nessa etapa, todavia, não é incomum o surgimento de situações incidentais apresentadas em juízo sobre as quais o julgador naturalmente tem o dever de se manifestar, como a produção de um laudo pericial relacionada à reclamação, por exemplo. O pronunciamento daí oriundo importará na denominada decisão interlocutória de cunho meramente instrutório que não resulta, todavia, em exame do mérito da demanda e, sequer finaliza o processo.

É possível, ainda, a ocorrência, em determinadas hipóteses, da necessidade de se proferir o julgamento parcial antecipado do mérito, como na apreciação de pedidos que se mostram irrefutáveis: nesta circunstância, havendo dois ou mais pleitos, o juiz está autorizado a julgar, desde logo, aquele considerado incontroverso (inc. I do art. 356). No que tange aos demais requerimentos constantes da inicial, o rito procedimental segue-se inalterado.

Essa situação, no Processo do Trabalho, é rotineira já que, habitualmente, são formuladas pretensões distintas em uma única reclamação trabalhista, observando-se, na prática forense, o julgamento antecipado de um ou de alguns dos pedidos pretendidos inicialmente, privilegiando-se assim o princípio da economia processual.

Logo, sob a ótica do CPC de 2015, a decisão judicial que julga antecipadamente e parcialmente o mérito da ação, é uma decisão de natureza jurídica interlocutória, não se finalizando, contudo, totalmente, a fase de cognição tampouco extinguindo in totum a fase de execução ( $§ 2^{\circ}$ do art. 203).

Corroboram com esse sentido Fredie Didier Jr., Rafael Alexandria de Oliveira e Paula Sarno Braga (2015, p. 307), para quem a "decisão interlocutória pode, então, em certos casos, resolver parte do mérito da causa de modo definitivo - apta à coisa julgada; assim podem ser rescindidas por meio da ação rescisória (art. 966, CPC de 2015)".

Nota-se que, no aludido rol, são consideradas decisões interlocutórias passíveis de desconstituição por meio de ação autônoma impugnativa, isto é, de 
ação rescisória, também aquelas em que o juiz julgar antecipadamente parte do mérito. Com efeito, essa é uma das modalidades de pronunciamento judicial com conteúdo finalizatório, ainda que parcialmente, já que não se apreciaram todas as pretensões.

Dessa maneira, não importa se a decisão tem ou não caráter interlocutório, para fim rescisório, basta que o mérito tenha sido apreciado e a aferição do trânsito em julgado tenha se consumado. Estando a decisão acobertada pelo manto da coisa julgada estará apta, então, a ser desafiada pelo instituto da ação rescisória, ainda, que seja apenas parte da decisão ( $§ 3^{\circ}$ do art. 966).

Seguindo-se o curso normal, observando-se o devido processo legal, o juiz a quem couber por distribuição a demanda, conduzirá as audiências de instrução e julgamento, instruindo o feito para, ao fim, deliberar coroando a fase de cognição, e então pronunciar-se mediante sentença na própria audiência, materializada formalmente por escrito nos autos do processo.

Para o atual Diploma Processual tal pronunciamento judicial previsto no $\S 1^{\circ}$ do art. 203 é o meio pelo qual, com fundamento nos arts. 485 e 487, o magistrado finaliza a fase cognitiva do procedimento comum, assim como extingue a execução, em $1^{\circ}$ grau de jurisdição. Em face dessa sentença, após o oitavo dia, prazo legal para interposição recursal, é possível rescindi-la pela via da rescisória, desde que atendidas as exigência legais.

Essa sentença prolatada de igual maneira se predispõe à interposição de recursos para o Tribunal Regional do Trabalho, e se sujeita ao julgamento pela vontade dos diversos membros componentes do Órgão colegiado detentor de tal competência.

A decisão colegiada decorrente do julgamento dos diversos tipos de recursos se consubstanciará em um acórdão (art. 204, do CPC). No que tange ao recurso ordinário (inc. II do art. 893 da CLT), este estará, igualmente, sujeito à impugnação por meio da rescisória, desde que constatadas as hipóteses previstas na legislação (art. 966 do CPC). Essa possibilidade ocorrerá se o vício oriundo da sentença prolatada no juízo a quo, for mantido pelo Tribunal Regional, hipótese em 
que tal pronunciamento será retificado no acórdão que vier a ser prolatado em fase de rescisória.

Outrossim, o julgamento dos processos de competência originária dos Tribunais do Trabalho e do Tribunal Superior do Trabalho, da mesma maneira, é realizado pelos seus Órgãos colegiados julgadores e a decisão prolatada pelos membros que os compõem se consuma também em um acórdão.

Renovando que a opção do legislador por "decisão de mérito [...]", na forma prevista no caput do art. 966 do CPC de 2015, em substituição à locução "a sentença de mérito" prevista no CPC de 1973, autoriza a consideração que, em relação a este aspecto, ampliou-se o campo de interpretação relacionado à sentença de mérito (BRASIL, 2015, grifos nossos).

Logo, levando em conta que a ação rescisória no âmbito da Justiça do Trabalho encontra-se disciplinada, supletivamente, pelas normas do Código de Processo Civil, aquiesce-se ao entendimento doutrinário contemporâneo, cuja interpretação relacionada à "sentença de mérito" mutatis mutandis passa a ser considerada a "decisão judicial", gênero das espécies sentença, acórdão, ou decisões interlocutórias meritórias proferidas pelo juízo singular.

Destarte, constata-se que os efeitos jurídicos produzidos pela decisão judicial de mérito, em quaisquer dessas modalidades interpretadas como substitutivas da expressão "sentença de mérito" outrora adotada, cujo trânsito em julgado tenha se operado e a coisa julgada formada, desde que não se afaste das possibilidades arroladas pelo art. 966 do CPC numerus clausus, são passíveis de rescindibilidade pela via da ação rescisória, com o propósito de impedir a cristalização de vícios procedimentais ou processuais.

\section{HIPÓTESES DE RESCINDIBILIDADE PELO NOVO CPC}


A despeito de a coisa julgada ter assento constitucional como direito fundamental, vedando-se ao Judiciário que decisões anteriores sejam novamente apreciadas, existem alguns pronunciamentos judiciais de mérito, nos quais o trânsito em julgado já se consumou que, por contrariarem cabalmente a lógica, não devem e não podem subsistir no mundo jurídico.

Diante dessa circunstância, o CPC de 2015, manteve no rol do seu art. 966 numerus clasus as causas que autorizam a rescindibilidade das decisões judiciais de mérito, transitadas em julgado, observando-se que algumas variações foram inseridas pelo legislador, esclarecendo, entretanto, que em sua maioria são de conteúdo meramente esclarecedor. No entanto, é preciso alertar que há possibilidade de rescisão de decisão judicial, cujo mérito não tenha sido apreciado, e esta é, talvez, a novidade mais significativa traçada pelo nominado art. 966.

A primeira causa de rescindinbilidade de decisão judicial de mérito, enumerada pela legislação processual civil, ocorre se constatado que tal pronunciamento foi dado com base na prevaricação, concussão ou corrupção do juiz (inc. I do artigo 966 do CPC). O magistrado que se desobriga de seguir a norma legal, substituindo-a unicamente para satisfazer o seu capricho, age com prevaricação. A concussão é atribuída a "quem abusa da sua qualidade e da sua função, para haver promessas de proveitos, ou por tê-las havido", assevera Pontes de Miranda (1998, p. 234). Já a corrupção se destaca nas hipóteses em que o magistrado solicita e recebe privilégios de modo ilegal e imoral, em benefício próprio ou de outrem.

As alterações ${ }^{2}$ inseridas pelo Estatuto vigente são quase imperceptíveis; todavia, os efeitos produzidos pela violação a tais possibilidades autorizam o desfazimento de decisão interlocutória de mérito, da sentença de $1^{\circ}$ grau de jurisdição e de acórdãos.

De igual forma a decisão judicial meritória, nas modalidades de decisão interlocutória, sentença proferida em $1^{\circ}$ grau de jurisdição ou acórdão cujo prevaricação, concussão ou corrupção de juiz” (BRASIL, 2015, grifo nosso). 
pronunciamento seja da lavra de juiz considerado impedido ou absolutamente incompetente, está sujeita à rescindibilidade pela via da rescisória (inc. II do art. 966).

Em relação a esse aspecto não houve mudanças. O legislador optou em manter a redação originária alterando apenas o vocábulo "dado" por "proferida", nada significativo, considerando-se que, em relação a tais motivações, essa previsão já era contemplada pelo CPC de 1973.

Nesse cenário, vale recordar que as causas de impedimento têm natureza objetiva e encontram-se elencadas no art. 144 do CPC; já a incompetência apta a gerar a ação rescisória se limita à incompetência absoluta, pela matéria ou pela hierarquia ou funcionalidade, não se prendendo às relativas, a exemplo dos critérios de incompetência territorial ou dos critérios de prevenção ou de conexão.

No que tange a pedido de rescisão de decisão judicial proferida com esteio em dolo, coação, simulação ou colusão, na forma prevista pelo inc. III do art. 966 do CPC, é nítida a ampliação introduzida pelo atual Código, visto que a legislação precedente previa tão somente o desfazimento do julgado em face de dolo ou colusão. Em verdade, porém, a ampliação das causas não alterou a intenção de se desconstituir a decisão contaminada de vícios, apenas acresceu, no aludido inciso, as possibilidade de desconstituição da decisão resultante de coação da parte vencida ou de simulação entre as partes, a fim de fraudar a lei.

Essas situações não são incomuns no sítio do Processo do Trabalho, especialmente tratando-se de sentença homologatória, resultado de ajuste dolosamente entabulado entre as partes, oriundo de lide simulada com a já citada finalidade de fraudar a lei. Desse modo, as partes (ativa, passiva ou mesmo o advogado representante legal) agem em conluio com o firme propósito censurável de formar título de crédito ilícito, porquanto se beneficiariam da natureza preferencial dos créditos trabalhistas.

Logo, no caso da utilização do processo, pelas partes, como instrumento para realização do ilícito, objetivando a obtenção de vantagem em detrimento dos legítimos credores, contrariando o ordenamento jurídico pátrio, a decisão judicial 
produzida a partir daí, frise-se que com o completo desconhecimento do magistrado, estará contaminada de vícios que autorizam a sua rescindibilidade.

A ofensa à coisa julgada prevista no inc. IV do art. 966 do CPC, em confronto com a legislação precedente em nada se alterou. Vale lembrar, todavia, que, se em determinada ação for pronunciada decisão que, transitada em julgado, e na qual se constata a coisa julgada material, e se, ulteriormente, nova decisão sobre a mesma matéria em cuja ação figuram as mesmas partes, o mesmo pedido e causa de pedir, é autorizada, então, a desconstituição do julgado.

Diante dessa circunstância, no plano fático, observando-se para tal as exigências processuais, pode-se concluir a imposição do manejo da ação rescisória para desconstituição da decisão meritória proferida em face da violação à coisa julgada.

Observa-se, em relação à violação manifesta da norma jurídica, cujo fundamento tem assento no inc. V do art. 966 do CPC, a alteração introduzida pela atual codificação, e seus efeitos são bastante significativos em confronto com o dispositivo correspondente da norma processual o qual previa "violar literal dispositivo de lei" (BRASIL, 2015).

Com efeito, a intenção do legislador foi permitir a ampliação desta possibilidade, porquanto a sua opção de não restringir a violação unicamente à "literal disposição de lei", considerando-se que isto faz parte de uma cultura obsoleta que não condiz com as exigências das relações jurídicas contemporâneas ou com a própria evolução do Direito.

A par disso, é possível concluir que a referida violação tem um campo mais vasto de interpretação, porque a afronta a princípio, regra ou postulado normativo, além do descumprimento de norma consuetudinária também passa a motivar a ação rescisória para o rescindir das decisões judiciais que afrontem os citados regramentos, garantem Luiz Guilherme Marinoni, Sérgio Cruz Arenhart e Daniel Metidiero (2015, p. 902).

Vale sublinhar a imprescindibilidade de a petição inicial da ação rescisória indicar explicitamente norma jurídica violada, não se aplicando ao caso o princípio 
iuri novit curi. Corroborando com este sentido, o Colendo Tribunal Superior do Trabalho consolidou entendimento consubstanciado no verbete sumular n. 408 segunda parte ${ }^{3}$.

Dessa feita, o fundamento do corte rescisório na forma dada à redação ao inc. V do art. 966 do CPC foi providencial, ajustando-se à realidade jurídica moderna, afastando em definitivo a orientação de outrora, baseada na desconstituição do julgado com fundamento meramente em violação literal de disposição de lei, possibilitando, então, a rescindibilidade da decisão judicial meritória, de igual maneira, a partir de outras hipóteses como as decorrentes da violação de princípio, de regra ou de postulado normativo, desde que a ofensa seja patente.

Com base na falsidade probatória é possível se desfazer a coisa julgada material, a teor do que dispõe o inc. VI do art. 966 do CPC. Embora, o atual CPC tenha registrado que essa prova deverá ser obtida após o trânsito em julgado, obviamente não há dúvida quanto a sua produção ao tempo do ajuizamento da reclamação trabalhista. A causa da desconstituição do julgado com base na falsidade probante deverá ser comprovada pelo autor (da rescisória) que, por razão de seu desconhecimento ou pela impossibilidade de acessá-la não pode dela fazer uso.

Ademais, é fundamental que a decisão judicial tenha sido baseada unicamente na prova falsa, ao passo que, se fosse verdadeira, o resultado final teria sido diverso. Então, é preciso que tal falsidade probatória tenha influenciado

\footnotetext{
${ }^{3}$ Súmula no 408 do TST AÇÃO RESCISÓRIA. PETIÇÃO INICIAL. CAUSA DE PEDIR. AUSÊNCIA DE CAPITULAÇÃO OU CAPITULAÇÃO ERRÔNEA NO ART. 966 DO CPC DE 2015. ART. 485 DO CPC DE 1973. PRINCÍPIO "IURA NOVIT CURIA" (nova redação em decorrência do CPC de 2015) - Res. 208/2016, DEJT divulgado em 22, 25 e 26.04.2016, Não padece de inépcia a petição inicial de ação rescisória apenas porque omite a subsunção do fundamento de rescindibilidade no art. 966 do CPC de 2015 (art. 485 do CPC de 1973) ou o capitula erroneamente em um de seus incisos. Contanto que não se afaste dos fatos e fundamentos invocados como causa de pedir, ao Tribunal é lícito emprestarIhes a adequada qualificação jurídica ("iura novit curia"). No entanto, fundando-se a ação rescisória no art. 966, inciso V, do CPC de 2015 (art. 485, inciso V, do CPC de 1973), é indispensável expressa indicacão, na peticão inicial da acão rescisória, da norma jurídica manifestamente violada (dispositivo legal violado sob o CPC de 1973), por se tratar de causa de pedir da rescisória, não se aplicando, no caso, o princípio "iura novit curia". (ex-Ojs nos 32 e 33 da SBDI-2 - inseridas em 20.09.2000). (BRASIL, 2016, grifo nosso).
} 
decisivamente a formação da convicção judicial nas suas razões de decidir. Além disso, esse deverá ser o único fundamento da decisão judicial que se busca rescindir.

A prova nova como uma das causas que autorizam o manejo da rescisória (inc. VII do art 966 do CPC), do mesmo modo que a falsidade probatória, deverá existir ao tempo do ajuizamento da demanda e, que por razões muito fortes, comprovadas judicialmente, a razão que levou a parte a não utilizá-la.

Nesse sentido, para Fredie Didier Jr. e Leonardo Carneiro Cunha (2016, p. 501) a prova nova deverá ser entendida como prova anteriormente existente, porém, acessível apenas após o trânsito em julgado.

Desse modo, é possível concluir que a prova nova apta a desfazer a coisa julgada material é específica, no sentido de já ter sido produzida em momento anterior, isto é, ao tempo da distribuição da reclamação trabalhista, não se prestando para desfazer o julgado qualquer prova produzida a posteriori.

Erro de fato constatado na decisão rescindenda também se sujeita à rescidinbilidade pela via da rescisória. Em verdade, o erro de fato calcado no inc. XIII do atual código equivale ao inciso IX do CPC de 1973, e tal erro sucede apenas quando a decisão judicial admitir um fato inexistente ou, na eventualidade de desconsiderar um fato realmente existente, decorrente de documentos colacionados aos autos do processo, ou mesmo atos procedimentais igualmente produzidos nos autos do processo. Todavia, é fundamental que tais fatos não representem questões controvertidas, sobre as quais o juiz deixou de se pronunciar. Nesse sentido é a inteligência do $\S 1^{\circ}$ do inciso em questão.

Em relação a esse aspecto, as alterações apresentadas com a nova codificação se limitam à troca de uma expressão por outra de igual valor e, portanto, consideram-se irrelevantes do ponto de vista de uma apuração mais sistematizada, já que o fundamento e as suas razões estão em consonância com a legislação processual substituída.

Para a sua caracterização como causa motivadora do desfazimento da coisa julgada material "supõe a afirmação categórica e indiscutida de um fato, na decisão 
rescindenda, que não corresponde à realidade dos autos", afirmam Francisco Ferreira Jorge Neto e Jouberto de Quadros Pessoa Cavalcante (2013, p. 1204). Importante, todavia, destacar a nova regra contemplada pelo $\S 2^{\circ}$ do mesmo artigo, inovadora em relação a todas as codificações pretéritas, sem qualquer correspondência, portanto, estabelecendo que

\footnotetext{
$\S 2^{\circ}$ nas hipóteses previstas nos incisos do caput, será rescindível a decisão transitada em julgada o que, embora não seja de mérito, impeça:

I - nova propositura de demanda, ou

II - admissibilidade do recurso correspondente (BRASIL, 2015).
}

Nota-se que, com o advento do CPC de 2015, autorizou-se o ajuizamento de ação rescisória em face de decisão cujo mérito não fora examinado, exigindo-se, para tanto, apenas o trânsito em julgado de tal pronunciamento. Nesse sentido, advertem Fredie Didier Jr. e Leonardo Carneiro Cunha (2016, p. 425) que as possibilidades apontadas pelo inc $\mathrm{I}$, do $\S 2^{\circ}$ retromencionado encontram-se arroladas no art. 485 c/c art. 486, ambas do mesmo Diploma Processual. Cuida, o citado primeiro artigo, das hipóteses em que o juiz põe termo ao processo sem, contudo, solucionar o mérito, dentre outros motivos, em decorrência do indeferimento inicial. Já o segundo artigo citado autoriza a interposição de ação em face de pronunciamento que não tenha solucionado o mérito.

Além disso, § 2o, II do art. 966 do CPC preconiza a possibilidade do cabimento de rescisória em face de decisão que não admite recurso. Isso significa que a decisão de denegar o seu seguimento será passível de desconstituição permitindo o seu conhecimento e julgamento pelo Tribunal a quo. Seguindo a mesma ordem de ideias, $0 \S 3^{\circ}$ do reiterado art. 966 do CPC, igualmente sem correspondência com o CPC de 1973, prevê a possibilidade do ajuizamento de pedido rescisório de apenas um capítulo da decisão judicial. Seria o caso de se impugnar pela via rescisória unicamente a parte da decisão que cuidou dos honorários advocatícios, exemplificam Fredie Didier Jr. e Leonardo Carneiro Cunha (2016, p. 434). 
Por fim, o $§ 5^{\circ}$ do art. 966 do CPC, com efeito, amplia as possibilidades de rescisão das decisões judiciais meritórias que contrariarem decisões baseadas em "enunciado de súmula ou acórdão proferido em julgamento de casos repetitivos que não tenham considerado a existência de distinção entre a questão discutida no processo e o padrão decisório que lhe deu fundamento" (BRASIL, 2015). Efetivamente, a inserção desse parágrafo ocorreu posteriormente ao advento do CPC de 2015 e apenas reforçou a possibilidade de rescisão do julgado na forma prevista pelo enunciado constante do inc. $V$ do mesmo artigo.

À vista disso, constata-se que do rol de causas que autorizam o desfazimento dos julgados, após o trânsito em julgado, deve-se destacar a relacionada à possibilidade de rescindir decisão judicial que, não tenha tido o mérito apreciado, contanto que não se afaste das exigências traçadas pelo mesmo dispositivo que a contemplou. Em relação aos demais preceitos considera-se que alterações não apresentam importância significativa, apesar de que, em algumas situações, a reelaboração do conteúdo da norma contribuiu para sua correta interpretação.

\section{COLMATAÇÃO DE LACUNAS: APLICABILIDADE DE NORMAS PROCESSUAIS CIVIL À AÇÃO RESCISÓRIA NO DIREITO PROCESSUAL DO TRABALHO}

A Consolidação das Leis do Trabalho não dispunha de qualquer dispositivo que autorizasse o ajuizamento da ação rescisória na esfera juslaboral. A ausência de tal previsão, a priori, deve-se ao fato de o texto constitucional outorgar tal competência exclusivamente ao Supremo Tribunal Federal, por meio do entendimento consolidado na Súmula de n. 338, de 1963 segundo a qual "não cabe ação rescisória no âmbito da Justiça do Trabalho" (BRASIL, 1963).

Essa orientação jurisprudencial, todavia, não ecoava solitariamente, pois o próprio Judiciário trabalhista corroborava com o mesmo sentido na forma consagrada no Prejulgado n. 10 da Corte Trabalhista. Essa concepção, entretanto, 
fora, a posteriori, revogada pelo então Prejulgado n. 16 o qual passou a admitir a ação rescisória na esfera da Justiça do Trabalho.

Ocorre que o reconhecimento dessa modalidade de ação na Justiça Obreira, por si só, não bastava. Isso porque as regras processuais relacionadas à procedimentalidade, desenvolvimento e julgamento desse instituto não foram contempladas pela CLT, que se limitou a estabelecer a sua aplicabilidade no campo juslaboral, de forma lacônica, no art. 836 da Consolidação, fazendo remissão à adoção de normas processuais civilistas atinentes a esse tipo de ação.

Assim sendo, partir de sua aceitabilidade no campo laborativo, as disposições voltadas para o seu desenvolvimento válido e regular seriam, então, os mesmos previstos no citado Diploma processual.

O primeiro impasse registrado referiu-se ao prazo para ajuizamento dessa ação, já que sobre esta questão a codificação processual nada dispunha, aplicando a regra civilista que previa um prazo decadencial de cinco anos. Tal previsão era, contudo, por princípio, incompatível com os objetivos e anseios do Direito do Trabalho, que passou a adotar o prazo bienal previsto no art. 11 da CLT, para postular quaisquer reparações de atos que infringissem dispositivos nela contidos. Isso sem qualquer efetivação normativa do entendimento.

As incertezas jurisprudenciais e doutrinárias não se encerravam por, aí, já que as singularidades das ações de Competência da Justiça do Trabalho requerem normas que estejam em harmonia com os princípios que regem este ramo da ciência jurídica impondo, portanto, a necessária agilidade para a solução das controvérsias, especialmente considerando-se a natureza alimentar das verbas rescisórias caracterizadas como créditos preferenciais.

Nesse contexto, a priori, o legislador se limitou a renovar a norma insculpida no já citado art. 836 da CLT, fazendo inserir, além do prazo bienal, a remissão às normas do CPC de 1973. 
ação rescisória, que será admitida, no prazo de dois anos, nos termos dos arts. 798 a 800 do Código de Processo Civil (BRASIL, 1967, grifo nosso).

Nota-se que as particularidades do Processo do Trabalho foram assim consideradas já quem o prazo bienal para o ajuizamento da rescisória na Justiça Laboral restou fixado, consoante ao entendimento prévio desta Justiça Especializada. Em momento posterior, todavia, o mencionado art. 836 da CLT, em redação ampla, indicou o Capítulo e o Título referentes ao disciplinamento de tal ação constantes do Código Processual Civil.

Com o advento do CPC de 2015, o legislador, evitando ressucitar as divergências pretéritas, previu as regras processuais civis aplicáveis no Processo do Trabalho no $\S 4^{\circ}$ do seu art. 1046, preconizando que "As remissões a disposições do código de processo civil revogado, existentes em outras leis, passam a referir-se às que Ihes são correspondentes neste Código". (BRASIL, 2015).

Destarte, muito embora seja natural o transplante de institutos de regras processuais entre os ramos da ciência jurídica, como o caso do instituto da ação rescisória na Justiça do Trabalho, isso requer a criação de procedimentos apropriados e adequados ao Processo do Trabalho. Não é o que ocorre, entretanto, em se tratando da ação rescisória trabalhista. A par disso, destaca Vitor Salino de Moura Eça (2016, p. 512) que "a procedimentalidade para as ações especiais é um grave e antigo problema do direito processual, pois a normatividade cria o padrão disciplinar, mas deixa de se ocupar do espaço procedimental no qual a ação deve se desenvolver".

Por fim, o art. 15 do CPC de 2015 atrai para si o regulamento do Processo do Trabalho, face a inexistência de normas processuais que regulem o instituto da rescisória no campo Laboral. Mas, tal previsão carece de ser avaliada com moderação, já que a necessidade de tal transposição afinada aos princípios que regem o Direito Processual do Trabalho deverá necessariamente imperar.

Evidencia-se mais que, em face das inovações contempladas pelo CPC de 2015, o manejo dessa ação na Justiça Laboral prossegue impondo o "constante esforço de adequação aos ritos conhecidos, em especial no campo do Direito 
Processual do Trabalho, porquanto a ação rescisória foi idealizada originalmente como uma ação civil", assevera Vitor Salino de Moura Eça (2016, p. 513).

Nesse cenário, importa registrar, todavia, o comando expedido pela Corte Trabalhista por meio da Instrução Normativa n. 203, de 2016 dispondo, de forma exemplificativa, acerca das normas do CPC de 2015, aplicáveis e as não aplicáveis ao Processo do Trabalho, destacando-se que as previsões contidas nos arts. 966 ao975 foram recepcionadas pelo Processo do Trabalho. Alguns regramentos, contudo, não o foram, a exemplo da inaplicabilidade do art. 219 do CPC pertinente à contagem dos prazos em dias úteis, permanecendo o entendimento de que, em função das particularidades inerentes aos processos que tramitam na Justiça do Trabalho e os fins Direito Processual do Trabalho, tal contagem far-se-á em dias corridos na forma já prevista pelo art. 775 da CLT.

A par disso, em face das lacunas ao instituto da rescisória no âmbito da Justiça do Trabalho, é possível afirmar que, a despeito da autonomia inerente ao Direito Processual do Trabalho, é premente a criação de normas processuais de aplicação exclusiva para reger essa modalidade de ação também na esfera laboral. Enquanto não se alcança essa independência, a aplicação das normas do código de processo civil subsistirão, obrigatoriamente, em face da rescisória trabalhista.

\section{CONCLUSÃO}

Durante longo período a conceituação clássica atribuída à "sentença de mérito", para fins de desconstituição pelo mecanismo da Ação Rescisória, limitou-se às sentenças resultantes do julgamento de reclamações trabalhistas, proferidas em 1ำ grau de jurisdição e aos acórdãos prolatados nos diversos recursos pelos Órgãos fracionários do Tribunal Superior do Trabalho e Tribunais Regionais do Trabalho. Não obstante tal tradição, observou-se que, com o advento do Código de Processo Civil de 2015, o lendário conceito foi ampliado passando-se a compreendê-lo também as decisões interlocutórias, como as que decidem antecipadamente uma parte incontroversa das reclamações trabalhistas. 
Importa registrar, então, que o novo conceito de "sentença de mérito" teve alargado seu campo de interpretação e assim, o desfazimento da res judicata igualmente ajustou-se ao atual entendimento, abarcando então decisões judiciais interlocutórias que enfrentam o mérito da matéria posta em apreciação.

O Direito não pode e não deve se estancar. As necessidades aos ajustes contemporâneos conclamam novos desafios, os quais impõem uma adaptação da ciência processual. $O$ modo de pensar hoje pode não ser o mesmo de amanhã porquanto o progresso constatado na rotina social, por óbvio, granjeia também essa ciência jurídica secular, desafiando a incessante e a inevitável harmonização nas relações jurídicas atuais. Nessa ordem de ideias, percebeu-se que o respeito ao julgado propicia a confiabilidade e segurança do jurisdicionado de maneira que o objeto debatido em uma determinada lide não comporte rediscussão ad eternum.

A despeito de tal necessidade o Diploma processual arrola numerus clausus as possibilidades e rescindibilidade das decisões judiciais, considerando ser utópica a busca da perfeição de tais decisões. Embora seja esse um dos objetivos colimados pelos magistrados trabalhistas, nem sempre os vícios da ilegalidade são completamente afastados, especialmente aqueles ocorridos alheios à sua vontade. Diante desse impasse e frente a inevitáveis decisões viciadas, desde que cumpridas as exigências legais, concluiu-se pela possibilidade do desfazimento da coisa julgada unicamente com fundamento nas causas elencadas pelo já citado e reiterado art. 966 do CPC. Nesse contexto, verificou-se ainda que, dentre os ineditismos promovidos pelo NCPC, previu-se como causa motivadora para o ajuizamento da rescisória a decisão judicial cujo mérito não fora apreciado.

A priori, o valor segurança jurídica deverá prevalecer; em determinadas situações, porém, o valor justiça deverá preponderar, e disto resulta o desfazimento dos julgados. Nesse contexto, é preciso enaltecer que, com o Estado Democrático de Direito, desabrocharam novos padrões, diretrizes, princípios e direitos fundamentais, conclamando uma postura proativa e dinâmica do Estado-Juiz na função da prestação da tutela jurisdicional. É com base nessa alegação que, 
eventualmente, carecem de inversão os aludidos valores, segurança jurídica e justiça.

Por fim, conclui-se que a total omissão da legislação trabalhista voltada especificamente para reger o instituto da ação rescisória na esfera da Justiça do Trabalho não encerra tanta novidade. Invoca-se, contudo, à comunidade jurídica a criação de normas processuais e procedimentais apropriadas e ajustadas a essa espécie de ação sui generis aplicáveis à realidade laboral, porquanto a adaptação da legislação alheia não atende a contento às peculiariedades que envolvem as ações de competência da Justiça Especializada. Afinal os direitos fundamentais dos trabalhadores, a dignidade da pessoa humana e o valor social do trabalho são garantias de indisponibilidade absoluta, e isso é inegável.

\section{REFERÊNCIAS}

BRASIL Decreto de Lei n. 229 de 28 de fevereiro de 1967. Altera dispositivos da Consolidação das Leis do Trabalho, aprovada pelo Decreto-lei no 5.452, de 1ㅇ de maio de 1943, e dá outras providências. Diário Oficial União, Brasília, 28 fev. 1967. Disponível em: < http://www.planalto.gov.br/ccivil_03/decreto-lei/Del0229.htm>. Acesso em: 19 fev. 2017.

. Lei n. 13.105, de 16 de março de 2015. Código de Processo Civil. Diário Oficial União, Brasília, 17 mar. 2015. Disponível em:

<http://www.planalto.gov.br/ccivil_03/_ato2015-2018/2015/lei/l13105.htm>. Acesso em: 19 fev. 2017.

Supremo Tribunal Federal. Súmula nํ3ㅇ. Supremo Tribunal Federal, Brasília, 1963. Disponível em:

$<$ http://www.stf.jus.br/portal/jurisprudencia/menuSumarioSumulas.asp?sumula=1572 >. Acesso em: 19 fev. 2017.

.Tribunal Superior do Trabalho. Súmula no 408. Diário Eletrônico da Justiça do Trabalho, Brasília, 22, 25 e 26 abr. 2016. Disponível em:

<http://www3.tst.jus.br/jurisprudencia/Sumulas_com_indice/Sumulas_Ind_401_450.h tml\#SUM-408>. Acesso em: 20 ago. 2017.

DIDIER JÚNIOR, Fredie; CUNHA, Leonardo Carneiro da. Curso de Direito

Processual Civil. 13. ed. Salvador: JusPODIVM, 2016. v. 3. 
DIDIER JÚNIOR, Fredie; OLIVEIRA, Rafael Alexandria de; BRAGA, Paula Sarno. Curso de Direito Processual Civil. 11. ed. Salvador: JusPODIVM, 2016. v. 2.

DINAMARCO, Cândido Rangel. Ação Rescisória, incompetência e carência de ação. Revista de Processo - REPRO. São Paulo, Revista dos Tribunais, n. 104, ano 26, out./dez. 2001.

EÇA, Vitor Salino de Moura. Ação Rescisória Trabalhista: Póstero e Percrutação. In: DALLEGRAVE NETO, José Affonso; GOULART, Rodrigo Fortunato (Coord.). Novo CPC e o Processo do Trabalho. 2. ed. São Paulo: LTr, 2016.

JORGE NETO, Francisco Ferreira; CAVALCANTE, Jouberto de Quadros Pessoa. Direito Processual do Trabalho. 6. ed. São Paulo: Atlas, 2013.

MARINONI, Luiz Guilherme; ARENHART, Sérgio Cruz; MITIDIERO, Daniel. Código de Processo Civil Comentado. São Paulo: Revistas dos Tribunais, 2015.

MIRANDA, Pontes de. Tratado da Ação Rescisória. Das sentenças e de outras decisões. Atualizado por Vilson Rodrigues Alves. Campinas: Bookseller, 1998. 